6-8 ft. in diameter the centre portion of which is heated to $2,100^{\circ} \mathrm{F}$. electrically. The copper molts and is by capillary attraction drawn into the joints. Oxidation is prevented by the tube being filled with a gas prepared by the action of steam at high tem. porature and pressure on illuminating gas. Beyond the welding zono the tube is cooled so that tho articles emorge at room temperature. Tho copper alloys with the steel at the joint and the alloy appears to bo stronger than the steel.

\section{Lectures on the Rothamsted Experiments}

Durixg the forthcoming winter, Mr. H. V. Garner, guide demonstrator at the Rothamsted Experimental Station, and other members of the staff are prepared to give a fow lectures to chambers of agriculture and horticulture, farmers' clubs, furm workers' associations, agricultural societies, etc., on the Rothamsted experiments. The subjects offered include manures, soil micro-organisms (bacteria, protozoa, etc.), agricultural botany, agricultural chemistry, soil physics, entomology, and plant pathology. No fee will be charged for the lecturers' services but travelling and other expenses must be defrayed. Further information can be obtained from the Secretary, Rothamsted Experimental Station, Harpenden, Herts.

\section{Gift to the University of Sheffield}

SiR ROBER'T HADFIELD, as head of the firm of Hadfields, Ittd., and by his generosity to the University of Sheffield, for which some years ago ho built and equipped a metallurgical research laboratory for the Ieprrtment of Applied Science, is well known to the citizens of Sheffield. He has now placed them still further in his debt by a gift of $£ \tilde{5}, 000$ to tho University, expressing the hope that it may form a nucleus for the establishment of a course in founding in the Faculty of Metallurgy. Sir Robert was president of the Iron and Steel Institute when it visited Sheffiold in 1905, and now, after an interval of twenty-eight years, the Institute has again held its annual meeting at Sheffield, the president being a friend of Sir Robert's, Mr. W. R. Lysaght, who was unfortunately prevented by ill-health from attending. It is to mark these two visits that Sir Robert has mado this generous gift to the University. The steel industry of to-day, still centred at Shoffield, owos much to metallurgical rescarch in which the universities have played their part, and Sir Robert's benefactions to the Univorsity of Shefficld are a fitting recognition of this debt and at the same time a gesture for the encouragement of so-called academic research.

\section{Institute of Metals}

The Institute of Metals will hold its silver jubilee autumn meeting in Birmingham on September 18-21, under tho presidency of Sir Henry Fowler. The Institute was founded in Hirmingham twenty-five years ago and it is appropriate, therefore, that the forthcoming meeting should bo held in that city. An inaugural lecture on "Twenty-Five Years" Progress in Metallurgical Plant" will be given by Mr. W. R. Barclay, vice-president, and a series of fourteen papers dealing with various phases of metallurgical work are to be delivered. A specially interesting feature of the meeting will be the reproduction of the first office of the Institute of Metals. This was housed in the Metallurgical Department of the University of Birmingham, and was set up by tho Institute's first and only secretary, Mr. G. Shaw Scott, who, with the president and the chairman of tho executivo committee, will receive the remaining original members of the Institute in the reconstituted office. Here visitors will have an opportunity of inspecting the earliest records of the Institutoincluding tho original membership applications and photographs taken during the inaugural meeting in 1908. During Mr. Shaw Scott's period of office as secretary and editor the membership of the Institute has increased from 200 to 2,200 . Whercas originally the membership was confined almost entirely to Great Britain, it now covers the whole world. The Institute removed in 1909 to London, where it now has offices at 36 Victoria Street, Westminster, S.W.1.

\section{Announcements}

Triw following appointments have recently been made in the Colonial Agricultural Service: Mr. A. C. Barnes, to be director of agriculture and Island chemist, Jamaica; Mr. I. L. Blunt, to be director of agriculture, Cyprus; Mr. H. B. Stent, to be agricultural chemist, Coffee Experimental Station, Tanganyika.

With reference to the paragraph in NATURE of August 19, p. 285, on the cluster variable numbered 65 by Bailey (who diseovered its variability, but not its period) it was stated that tho period was first found by Mr. Kooremann. This is incorrect. The period was actually determined by Prof. F. Hertzsprung.

A Biblography of the scientific papers of Sir James Dewar and his colleagues from 1867 until 1923 has recently been published in a limited edition of two hundred copies, price 5s. Copies may be obtained from Mr. H. Young, 16, Causton Road, London, N.6.

Applications are invited for the following appointments, on or before the dates mentioned :-A principal teacher of mathematics and physics at the Technical College, Coatbridge-.The Director of Education, Lanarkshire Houso, 191, Ingram Street, Glasgow (Sept. 23). An assistant inspector of scientific supplies-Tho Director-General, India Store Department, Belvedere Road, Isamboth, London, S.E.1 (Sept. 25). A drainage engineer for the Governmont of Bihar and Orissa-The High Commissioner for India, General Department, India House, Aldwych, London, W.C.2 (Sept. 26). A principal of Dudden Hill Technical Institute, Denzil Road, Willesden, London, N.W.10-H. M. Walton (H.), 10, Great Georgo Street, Westminster, London, S.W.I (Oct. 7). An agricultural bacteriologist in the Punjab Agricul. tural Service, Class 1-.The High Commissionor for India, General Department, India House, Aldwych, London, W.C.2 (Oct. 7). A lecturer in agriculture at the Cheshire School of Agriculture, Reaseheath, Nantwich-The Principal (Oct. 7). 